\title{
Az atipikus foglalkoztatási szerződések néhány problematikus kérdése a mezőgazdaságban Prugberger Tamás ${ }^{*}$
}

\begin{abstract}
A tanulmány a mezőgazdaságban alkalmazott speciális foglalkoztatási formákat mutatja be. Ennek során bemutatja azokat, amelyeket a családi gazdaságokban alkalmaznak és amelyeket a nagy gazdaságokban. Az előbbiek a családtagi munkavégzés, míg az utóbbira a munkaszerződéses foglalkoztatás, az egyéni és a csoportvállalkozási, valamint a részesművelési forma a jellemző. $A z$ agrárszövetkezetek esetében gyakori a tagsági viszonyon alapuló munkavégzés is. Szó esik továbbá arról is, hogy a tanulmányban tárgyalt munkavégzési formák közül melyek azok, amelyek ma is időszerüek.

Kulcsszavak: családi farm, szerződéses farm, részesművelés, felesbérlet, családtagi munkavégzés, tagi munkavégzés, csoportos vállalkozás, idénymunka, vállalkozási típusú munkaszerződés
\end{abstract}

\section{Problematic issues of non-standard employment contracts in agriculture}

The study presents special forms of employment that are used in agriculture. In doing so, it presents those that are used on family farms and those that are used on large farms. The former are characterized by family work, while the latter is characterized by employment, individual and group entrepreneurship, and part-time farming. In the case of agricultural cooperatives, work based on membership is also common. Furthermore, the study also deals with those forms of employment in connection with the study that are still relevant nowadays.

Keywords: family farm, contract farm, part-time farming, family lease, family work, member work, group work, seasonal work, business type employment contract

DOI: $10.32980 / M J S z .2021 .1 .949$

\section{A mezőgazdasági tevékenység és az e tevékenységből eredő foglalkoztatás sajátosságai}

mezőgazdasági tevékenység ellentétben az ipari termelő üzemek és a kereskedelmi, valamint a vendéglátóipari gazdasági egységek tevékenységével és az ottani foglalkoztatással szembeni jellege kevésbé folyamatos és egy része annál fogva, hogy a tevékenység egy jelentős része nem helyhez kötött és a szabad ég alatt a természet, vagyis a termőföldeken és szakaszokra bontva bonyolódik le, nem, vagy csak részben lehet beilleszteni a tipikus munkavégzési és foglalkoztatási formák közé. Az állatgondozási tevékenység beilleszthető a munkajogra jellemző általában napi 8 órában meghatározott foglalkoztatási időtartamba, ami nemcsak tipikus munkaviszony, hanem tartósvállalkozási formában is megvalósítható. Az állatgondozás és az

\footnotetext{
* Professor emeritus, Miskolci Egyetem, Állam- és Jogtudományi Kar, Civilisztikai Tudományok Intézete, Munka- és Agrárjogi Intézeti Tanszék.
} 
állattenyésztés, valamint az állaltnevelés ilyen természetü még ezen kívül a segédüzemágként működő gépi kiszolgálás, valamint a mezőgazdasági gépi eszközeinek karbantartása gondozása és javítása. Ezzel viszont szöges ellentétben áll a növénytermesztés, ahol a munkavégzés nem körülhatárolt olyan zárt helyen történik, ahol a foglalkoztató vagy az általa kijelölt müszakvezető képtelen ellenőrizni, hogy minden egyes foglalkoztatott az elő́rásoknak megfelelően látja el munkaköri feladatait. Ezért a mezőgazdaságban az ilyen jellegü atipikusnak elkeresztelt foglalkoztatások sokkal szélesebb körűek, mint a lokálisan lehatárolt helyen, vagyis üzemben történő foglalkoztatás, ahol az üzembirtokos, vagy annak megbízottja elvileg permanensen ellenőrizni tudja a munkafolyamatokat és megelőzni a munkabaleseteket, valamint a munkavállalók által hanyagságból okozott egyéb károkozásokat. Ennél fogva, míg a legtöbb gazdasági ágazatban folyó munkavégzésnél a tipikus munkaviszony azáltalános és az atipikus foglalkoztatás a kivétele forma, addig a mezőgazdasági tevékenység körében a helyzet pont ennek a fordítottja. A következőkben az ebből eredő eltéréseket és problémákat járjuk körül.

\section{Atipikus foglalkoztatási formák a növénytermesztés területén}

\subsection{A foglalkoztatás sajátosságai. A mezőgazdasági tevékenység} alapstruktúráját illetően a II. Világháború befejezése előtt Magyarországon is hasonló volt, mint Közép-, és Nyugat-Európa több országában. Ezen a téren alapvető változásra csak azokban közép-, és kelet-európai országokban került sor, amelyekben a szovjet érdekszférához történt kerülésük folytán a kis-, és a középgazdaság „szocializálására”, vagyis államosítására, vagy szövetkezetesítésére került sor. Addig ugyanis az ugyancsak egyéni, valamint kereskedelmi társasági magántulajdonban álló termeló-, és vendéglátó ipari, továbbá kereskedelmi gazdasági vállalkozások egyfelől kis és középüzemekre, másfelől nagy gazdasági egységekre tagozódtak, ahogyan ez a nyugat-európai országokban ma is fennáll. Ugyanez vonatkozott és vonatkozik a rendszerváltás után a volt szovjet érdekszférából az 1990. évi rendszerváltással kikerült posztkommunista közép-, és kelet-európai államokra, így Magyarországra is. Ennél fogva, miként az iparban és a kereskedelemben a kisiparos és a kiskereskedő, valamint kisvendéglős elsősorban családi munkaerővel és esetleg néhány alkalmazottal, segéddel dolgozik, ami a közepes gazdaságoknál már általános jelenséggé válik, addig a nagy gazdasági egységeknél, a gyáripar termelöüzemeinél, az áruházaknál, szálódával egybekötött éttermeknél a nagyszámú munkavállalóval történő üzemelés a jellemző. Ez vonatkozik a mezőgazdaágra is, ahol a kis-, és közepes gazdaságokra a családi alapon történő munkavégzés a jellemző, ahol a méret növekedéstől függően növekszik az állandóan foglalkoztatott mezőgazdasági munkavállalók, korábbi terminológiával élve a mezőgazdasági (külső) cselédek száma. A munkaszervezés tekintetében ezért a kis és a közepes méretü gazdaságokat családi farmoknak (family farm), míg a nagyméretü gazdaságokat szerződéses farmoknak (contract 
farm) tekinti az agrár-szakirodalom. ${ }^{1}$

Eme alapstruktúrán belül azonban a mezőgazdaságnak és a mezőgazdasági munkavégzésnek megvannak a maga sajátosságai részben az állandó odafigyelést igénylő állatgondozás és állatnevelés, részben pedig a szabadban, az időjárás függvényében történő munkavégzés. A mezőgazdasági munkavégzés ritmusa ezért erősen függ az állatok egészségi állapotától, a váratlan megbetegedésektől, valamint az időjárás változásaitól, amelyhez igazodnia kell a növénytermesztésben egyénileg vagy csoportosan dolgozó mezőgazdasági munkásoknak. Éppen ezért írják elő több európai országban a mezőgazdasági törvények, hogy farmot, és farmgazdálkodás céljaira termőföldet az vásárolhat, aki a gazdaságának területén, vagy annak közelében, attól meghatározott távolságon belül lakik. ${ }^{2}$ Ennek megfelelő szabályt tartalmaz a mezőgazdasági földforgalomról szóló 2013-ik évi CXXII. törvény is. ${ }^{3}$ Sőt, a mezőgazdasági munkajogviszonyt a II. Világháború befejezéséig szabályozó 1935: II. t. c.-el kiegészített 1907: XLV. t. c. 20. §-a kimondta, hogy a gazdasági cseléd részére az őt foglalkoztató farmtulajdonos munkaadó természetbeni bérként szolgálati lakást biztosítani volt köteles, a felfogadott cselédnek pedig a reá megállapított munkavégzés időszakában állandó jelleggel jelen kellett lennie, ha pedig valamilyen okból távol kellett attól lennie, a fenti törvénycikk 15 . $\S$-a értelmében helyettes beállitásáról volt köteles gondoskodni. Ugyanígy a vezető alkalmazotti munkakört betöltött intézőknek és gazdatiszteknek is a farmon kellett lakniuk és a szolgálati idejük alatt ott tartózkodniuk. Mezőgazdasági munkavállalónak számított, aki legalább egyhavi, vagy azt meghaladó időre napszámosnak vagy más munkakörbe helyezkedett el farmgazdaságban $\mathrm{Az}$ állandó gazdasági cselédek munkaviszonya ellenkező megállapodás hiányában egy gazdasági évre szólt, amely azonban további egy évre többször is korlátlanul hosszabbítható volt. A gazdatisztek munkaviszonya főszabályként határozatlan időre szólt. ${ }^{4}$ A mezőgazdasági munkavállalók a világháború előtti kapitalista Magyarországon a munkakörük szerint is két kategóriába voltak osztva, ami a társadalombiztosítás szempontjából volt jelentős. Ugyanis az általános kategóriába tartozó gazdasági cselédeket baleset szempontjából a farmtulajdonos nem volt köteles biztosítani, de a gép mellett dolgozókat az 1913: XX. t. c. értelmében igen. A mezőgazdasági munkaviszonyban

\footnotetext{
${ }^{1}$ Imrik Stanek: Die Landwirtschaft in Ost und West. Verlag Umler, Stutgart

${ }^{2}$ A gazdaság területén, illetve annak közelében történő helyben, illetve hely-közelben lakást a szerző fél részére mezőgazdasági termőföldszerzés feltételéül a dán és a svájci jogi szabályozás szigorúan előírja, csak ügy, mint az alapfokú mezőgazdászi képesítést is. Más nyugat-európai államokban szintén fennállnak hasonló előírások, de azok kevésbé merevek és rugalmasabban vehetők figyelembe. Ilyen pl. a német, valamint az annál valamivel kötöttebb francia szabályozás. Országonkénti bemutatását az eredeti források megjelölésével lásd: Prugberger, A mező-, és erdőgazdasági földingatlan tulajdonjogának, használatának-hasznosításának és jogátruházásuk szabályozásának lehetőségei az uniós jog tükrében. In: Az európai földszabályozás aktuális kihívásai. (Szer: Csák Csilla-Szilágyi J. Ede). Novotni Alapítvány, Miskolc és a Licinium Art Könyvkadó Kft. közös kiadása Miskolc

3 A 2013. évi magyar Földforgalmi Törvény csak a mezőgazdaságban való jártasságot tanúsító képesítést írja elő direkt jelleggel, a helyben, illetve a hely-közelben való lakást, letelepülést csak közvetett módon az elővásárlásra és az elö-haszonbérletre vonatkozó sorrendtartás tekintetében.

${ }^{4}$ Vincenti Gusztáv: A munka jogviszonyai. In: Szladits Károly (főszerk.) Magyar magánjog. IV. kötet, Kötelmi jog különös része. Grill Károly Könyvkiadó, Bp. 1942. (Továbbiakban: Szladits) 389. o.
} 
a kötelező öregségi, rokkantsági és halál esetére szóló biztositás csak későn került bevezetésre. A gazdatisztek vonatkozásában az 193: XXXVI. t. c.-el, míg a gazdasági munkavállalók esetében két évvel később az 1938: XII. tc.-el, amely csak az öregségi biztosításra terjedt $\mathrm{ki}^{5}{ }^{5} \mathrm{~A}$ mai agrár-munkajogi és társadalombiztosítási jogi szabályozás jogforrásilag sem különül el sem a természetbeni bérezés, sem a társadalombiztosítás vonatkozásában az egységes szabályozástól. A szolgálati lakás biztosítása elöírva nincs. A farmtulajdonosnak azonban érdeke, hogy az olyan agrármunkaköröknél, ahol állandó jelenlét szükséges, olyan munkavállalót alkalmazzon, aki közel lakk a gazdasághoz, vagy ha ilyen munkavállalót nem talál, akkor, akit felvesz, annak és családja részére megfelelő lakhatásról gondoskodjon. A kötelező társadalombiztosítás ma teljesen egységes, ugyanakkor viszont a gazdaság minden területén probléma, hogy a munkáltató részéről történő járulékfizetéshez történő hozzájárulás túlméretezett, amit igyekeznek a munkáltatók a mezőgazdaságban is kikerülni. ${ }^{6}$ Ennek tudható be, hogy a farmgazdaságok -különösen a kisebbek és a közepesek-jobb esetben munkaszerződés helyett formális tartós vállalkozási szerződést kötnek alkalmazottaikkal, rosszabb esetben pedig feketén alkalmazzák őket.7 Mindezek ellenére a mai mezőgazdasági tevékenységben és munkavégzésben mindenütt, így külföldön és Magyarországon egyaránt fennállnak olyan sajátosságok, amelyeket figyelmen kívül hagyni nem lehet.

A mezgazdaságon belül mindenekelőtt a növény és a gyümölcstermesztés, valamint a szőlészet és a borászat területén számos olyan szabadtéri tevékenység található, amelyek nem folyamatos jellegűek, hanem idénytől és évszaktól függően szakaszosan és igen gyakran nem is egyenletesen jelennek meg. Az un. növénytermesztés területén ezek a munkálatok nem egyszer kampányszerúen jelentkeznek. Ilyen a vetési időszak, az időszakosan visszatérő növényvédelmi, permetezési és öntözési tevékenység, valamint a termés betakarítása, learatása, ide értve a gyümölcs és a szőlőszüretelést is. Mindez folyamatos normál napi munkavégzést nem igényel, ugyanakkor a szaggatott idénymunka, amely a tavasztól őszig tartó napjárás függvényeként félkör alakú jelleggel hosszabbodó, majd rövidülő napszakokban nyilvánul meg és szabadtéri tevékenységet nemcsak hogy nem igényel, de nem is tesz lehetővé. Ezen kívül egyes tevékenységek munkadömpingként jelennek meg, föleg az aratás és betakarítás időszakában. A nagykiterjedésű szőlő-, és gyümölcs-ütetvényeknél, de ugyanígy a konyhakerti növényeknél is az időközönként szükségessé váló gyomirtás nagyobb mérvü munkaerő kapacitást igényel.

A növény-termesztésnél e körülmények összekapcsolódva az időjárás kedvező és kedvezőtlen jellegének változásaival a szabadtéri munkát erőteljesen hullámzóvá teszi. Emiatt a szűk irányító agronómusi tevékenységen kívül a többi munkát nem

\footnotetext{
${ }^{5}$ Vincenti, in: Szladits, 604-605. o.

6 1997: LXXX. tv. (A tb. ellátás és szolgáltatásainak fedezetéről) IV. fejezet 19-21. §§; V.ö: Károlyi Géza-Prugberger Tamás: A társadalmi biztosítás fedezetrendszerét érintő jogi szabályozás időszerü kérdései. Új Magyar Közigazgatás, 2018/2. sz. 26-27. és 32-33. o. (Károlyi által írt rész).

7 Mélypataki Gábor: A mezőgazdasághoz kapcsolódó idényjellegü és közfoglalkoztatási jogviszonyok jellemzői. In: Agrár és környezeti jog 2017/23. sz. 84. o. (2.2. pont)
} 
gazdaságos tipikus munkajogviszonyban álló olyan munkavállalókkal elvégeztetni, akik napi nyolc órában határozatlan ideig tartó munkaviszony keretében lennének foglalkoztatva. A kisebb gazdaságokban a növénytermesztés nagyobb horderejü idényjellegű munkáit is legtöbbször a gazda a saját és családtagjai munkaerejével végzi el, alkalmi munkavállalókat azonban a legtöbbször felvesz. A legtöbb esetben gazdasági társaságként müködő nagy farmgazdaságok a nagyobb idénymunkákra vagy alkalmi munkavállalókat fogadnak fel, ${ }^{8}$ vagy pedig kiadják részesmúvelésbe a zöldség-gyümölcs, valamint a szőlőterületeket felosztva az erre jelentkezők között. ${ }^{9}$ Ilyen módon elkerülhetővé válik kedvező időjárás esetén napi 10-12 órás, kedvezőtlen időjárás esetén pedig legfeljebb néhány órás napi munkavégzésnek a mezőgazdasági munkának idény jellege miatt tizenkét hónapos munkaidőkeretbe foglalt nyilvántartása a túlórakorlátok átalányformájú betartása, és a munkavállalók részére kifizetendő túlmunkapótlékok elszámolása végett. ${ }^{10}$

\subsection{A családi és a családi társas gazdaságon belüli munkavégzés} sajátossági. Ami a családon belül a családtagi munkát illeti, korábban a 86/613. sz. EGK. irányelv rendezte, amelyet azonban a 2010/41. Sz. EK. irányelv hatályon kívül helyezett, megtartva azonban a 79/7. sz. EGK. irányelvben a családtagi munkát nem munkaviszonyban végző egészség- és nyugdíjbiztosítás kötésének a lehetőségét. A 2010/41. Sz. irányelv csupán az önfoglalkoztatásra vonatkozó szabályozást helyezte hatályon kívül 613. sz. irányelvből, átvette azonban abból a családtagi jogviszonyra vonatkozó társadalombiztosítás lehetőségét, valamint a munkaviszonyban állókkal fennálló egyező bánásmód betartására vonatkozó előírásokat. Ettől függetlenül azonban a családtaggal is létesíthető munkaviszony. Így a családtaggal is köthető munkaszerződés. Abban az esetben, ha az nem idényjellegű munka, hanem állandósult egy vagy több müszakra megállapítható fix munkaidőtartamra, többnyire napi 8 , illetve heti 40 óra időtartamban munkavégzésre szól, ${ }^{11}$ a Munka Törvénykönyvének a tipikus munkaviszonyra vonatkozó általános szabályai az irányadók. Ez vonatkozik arra az esetre is, hogy ha a családtag munkaideje meghaladhatja a heti 48 órát és a főszabályként érvényes két nap közötti 11 órás pihenőidő a családtagok, azaz a közeli hozzátartozók esetében 8 órai időtartamra lerövidíthető. ${ }^{12}$ Mindez azonban szintén

8 Juhász Pál-Prugberger Tamás: Munkaszervezetek - vállalkozási rendszerek a mezőgazdaságban. In: Tervgazdasági Fórum, 1/1987. 98. s köv. o.

9 Előző jegyzetben hiv. mü, 101-105. o.; Prugberger: Tagsági megállapodások a szövetkezetekben, Közgazdasági és Jogi Könyvkiadó, Budapest, 1979. 70-78. és 212-227. o.

10 Mt. 94. § (2). bek. d. pontja alapján idényjellegü munkavégzés esetében a főszabálykénti munkaidőkeret felmehet 6 hónapra, a korábbi (1992. évi) Mt. esetében 12 hónapra, azonban a mostani Mt. itt említett szakaszának (3). bek-e értelmében fenn áll a munkaidőkeretnek 12 hónapban történő megállapításának a lehetősége, "ha azt technikai vagy munkaszervezési okok indokolják." Az idényjellegü mezőgazdasági munkáknál viszont az ilyen okok fennállnak. A korábban kialakult gyakorlat ennél fogva ma is alkalmazható.

11 Ezzel kapcsolatban jegyzem meg, hogy a laikus közfelfogással szemben, amely a mezőgazdasági munkát főszabályként idényjellegú munkának tekinti, helytállóan mutat rá Mélypataki arra, hogy a mezőgazdasági munkának csak egy része idényjellegü, ezért azt kiterjesztően értelmezni nem lehet és a munkavégzés e miatt csak az adott munkafolyamat alapján minősíthető idénymunkának. L. Mélypataki, 7. sz. alatt hiv. mü, 79. o. (2.1. pont)

12 Mt. 104. § (2). § 
nyilvántartást igényel, ezért szintén annak mellőzése érdekében a társadalombiztosításra is lehetőséget adó családtagi munkavégzésre jelenti be családtagjait a gazdaság tulajdonosa és az Mt. adta lehetőségeket kihasználva az azonos joghatás miatt így jár el annak az agrárgazdasági társaságnak a tagja is, aki a társaságnak $25 \%$-ot meghaladóan a tulajdonosa. ${ }^{13} \mathrm{Ez}$ valamennyi gazdasági társaságra vonatkozik, kiindulva a legegyszerübbtől, a közkereseti társaságtól a legbonyolultabbig, vagyis a részvénytársaságig, kivéve azonban a szövetkezetet, mivel ott a korlátozott tőkekamat és tőketulajdon elve érvényesülés következtében minden tagnak csak egy részjegye számít be a tag tulajdonosi részesedésébe. Mivel a családi gazdaságon belül a családtagok munkaviszonyban vagy családtagi munkavégzése között a társadalombiztosítási járulék összege tekintetében különbség csak akkor áll fenn, ha a családtag a keresményével saját maga kíván gazdálkodni, akkor munkaszerződést kötnek a felek, egyébként azonban nem, mivel a járulék összege ténylegesen azonos az előbbivel, viszont az adminisztráció kevesebb. Ezért közös pénzgazdálkodás esetén a munkaszerződés-kötés elmarad.

\subsection{A csoport-munkavállalás, többnyire a nagyméretü gazdaságokban.} Sokkal bonyolultabb a helyzet a nagygazdaságok esetében, ahol valamikor a földbirtokosok, a nagy és középfarm-gazdaságokat bérlők, valamint a jól müködő középméretű családi farmok határidős munkaszerződéseket kötöttek alkalmi mezőgazdasági munkák elvégzését vállaló egyénekkel, valamint csoportosulásokkal, mint amilyenek a cséplő és aratóbandák voltak. ${ }^{14} \mathrm{Az}$ ilyen csoport-munkavállalók önszerveződési alapon nem csak egy idényre, hanem több idényre is egymással legtöbbször csak szóban társulási megállapodást létesítettek, amelyben egyhangú vagy többségi megegyezéssel megbízták az egyik, arra legalkalmasabb társukat, hogy a munkáltató, ill. a foglalkoztató gazda vagy farmgazdasági cég előtt képviselje a munkacsoportot, kösse meg nevükben is a munkaszerződést. ${ }^{15}$ Azonban ebben az estben is úgy kellett tekinteni, mintha a munkaadó a munkacsoport mindegyik tagjával külön munkaszerződést kötött és külön munkaviszonyban áll vele. ${ }^{16} \mathrm{~A}$ munkavégzésnek ezt az atipikus formáját ma az Mt. 195. §-a szabályozza. Tekintettel azonban arra, hogy ha a farmtulajdonos, illetve az agrárgazdaság ügyvezetője az ilyen szerződést a csoporttal teljes munkaidőre kötné meg, akkor abból kiindulva, hogy a munkacsoport minden tagja teljes munkaidőben dolgozik, a munkáltató cég minden egyes munkavállaló után a kötelező társadalombiztosítás járulékának a magyar jog szerint több mint háromnegyedét köteles viselni, a csoport-tagok pedig alig az egynegyedét. ${ }^{17}$ Ezért az ilyen osztott munkaszerződés-kötésre nem is kerül sor, hanem a csoporttal, mint

\footnotetext{
${ }^{13}$ Mt. 92. § (2). bek. 2. pont és (3). bek.

${ }^{14} \mathrm{~L}$. az 1 . sz. jegyzetet

${ }^{15} \mathrm{U}$. ott

16 Vincenti Gusztáv, A munka jogviszonyai. In Szladits Károly (szerk.): Magyar Magánjog. IV. kötet, Kötelmi Jog Különös Része. Grill Károly Könyvkiadó V. Budapest, 1942. (Továbbiakban: Nagy Szladits) 557. 0.

${ }^{17}$ L. a társadalombiztosítás fedezetéről szóló 1997:LXXX. tv-t és az Adózás rendjéről szóló 2003:XCII. tv.-t; $\mathrm{Az}$ ide vonatkozó rész részletes bemutatását Károlyi Géza - Prugberger Tamás: A társadalombiztosítás fedezetét érintő jogi szabályozás időszerű kérdéseihez c. tanulmányát. Új Magyar Közigazgatás, 2018/1. sz. 26-32. o.
} 
társasággal vállalkozási szerződést köt. Az Mt. fenti szakaszában meghatározott több személy között létesülő osztott munkaszerződés itt nem alkalmazható, már csak azért sem, mert e hagyományos és egyes helyeken ma is alkalmazott ilyen "brigád" munkavégzésnél a csoport-tagok között a munkák adminisztratív jellegü megosztására nem kerül sor. Ennél fogva tehát az Mt. 195. §-a szerinti több munkavállaló között történő munkaszerződés-kötés alkalmazhatatlan, mivel sem a munkaidő, sem pedig a munkavégzés a munkacsoport tagjai között a munkáltatóra is kihatóan nem kerül. Itt lényegében a csoporton belül informális jelleggel hasonló munkavégzés és elszámolás érvényesül azoknál a gazdasági társaságoknál és szövetkezeteknél, ahol a tagok személyes tagi közremúködésként végzett munkájuk alapján kapnak munkájuk után díjazást.

\subsection{A részesmüvelés és kifejlődése a termőföld-haszonbérleti} szerződésből. Miként már erről eddig is több ízben említés történt, a közepes és nagyméretű farmgazdaságokban a növénytermesztés vonalán a leggyakoribb foglalkoztatási forma $a z$ un. részesmúvelés. ${ }^{18} \mathrm{~A}$ részesmúvelés az olyan mezőgazdasági földhaszonbérleti szerződésből alakult ki, ahol a földtulajdonosnak járó haszonbérleti díj részben vagy teljes egészében a haszonbérelt földön a haszonbérlő által megtermelt termés egy részében kerül megállapításra. Ennek a legtöbb esetben alkalmazott formája az un. "feles-bérlet", ahol a termés fele, vagy egy része képezi a haszonbérleti díjat. ${ }^{19}$ A termőföld-haszonbérnek ilyen, természetben történő megállapítását az ENSZ-nek a Nemzetközi Munkaügyi Szervezete (ILO) által megkötött egyezménye jogellenesnek tartja azon az alapon, hogy ilyenkor olyan jogellenes bujtatott munkaszerződésről van szó, amelynél az ILO által a munkabérnek a természetbeni díjazásnak a pénzbeli díjazáshoz való aránya meghaladja, az egyezményben megállapított 50 \%-ot meghaladó arányát. Ugyanis az ILO és ennek megfelelően eme ILO egyezményt aláíró európai államokban, ha a haszonbérleti díjat természetben állapítják meg, a haszonbérleti szerződéssel egy olyan jogellenes munkaszerződést palástolnak a felek, ahol a munkadíj az ILO egyezménnyel szemben meghaladja a munkabér természetben történő meghatározásának maximum $50 \%$-os mértékben megállapítható korlátját. ${ }^{20}$ Bár Magyarország ezt az ILO egyezményt aláírta, nem követte az többi eme egyezményhez csatlakozott többi európai államot, amelyek a haszonbérleti díj természetben történő megállapítását kifejezetten tiltják. ${ }^{21}$ Ugyanis az 1990. évi rendszerváltást követő első, 1995-ik évi Földtörvény „expressis verbis" lehetőséget adott arra, hogy a földhaszonbérleti szerződésnél a haszonbérleti díjat teljes egészében a termés meghatározott arányában állapítsák meg a felek. Ugyanígy

\footnotetext{
18 Prugberger: Tagsági megállapodások a szövetkezetekben, Közgazdasági és Jogi Könyvkiadó (KJK), Budapest, 1979. 212-223. o.; U.ő: A szövetkezet és a tagok vagyoni, valamint vállalkozási kapcsolatainak jogi kérdései. Szövetkezeti Kutató Intézet, Közlemények. 15. kötet. SZÖVORG, 85. S köv. 0 .

19 Prugberger Tamás: A haszonbérleti szerződésről delege lata és de lege ferenda. In: Publicationes Universitatis Miskolciensis, Sectio Iuridica et Politica, Tomus XXI. (2004). 463-466. o.

${ }^{20}$ Iura Europae (Droit du travail -Arbeitsrecht), Edition technique iuris chasseurs -C. H. Beck Verlag, München-Berlin. I-III. 10-90. 10.

${ }^{21}$ L. előző jegyzetet, továbbá a munkajogi ország-jelentéseket, in Hennsler/Braun: Arbeitsrecht in Europa. Dr. Schmidt Verlag, 2. Auflag, Köln, 2011.
} 
lehetőséget adott arra is, hogy bármely agrárgazdaság részesművelésbe adhatta a földterületét, ahol a termőföld-, gyümölcsös-, és szőlőtulajdonos a részesművelővel ugyancsak a pénzbeli munka-, vállalkozási-, illetve részesművelési díj mellett megállapodhatott a részesművelési díjnak a termés meghatározott arányának az átadásában. ${ }^{22} \mathrm{~A}$ részesmúvelési szerződés egyébként csak annyiban tér el a haszonbérleti szerződéstől, hogy ott a részesművelésbe adó földtulajdonos közremüködik a termelésben. A részesművelésnél ugyanis a termeléssel kapcsolatos egyes munkafázisokat, így pl. a vetést, az öntözést, vagy a növényvédelmet a részesművelésbe adó végzi el. Részesművelés esetében a termesztéssel kapcsolatos egyes munkafázisok megosztásra kerülnek a részesmüvelésbe adó és a részesművelésbe vevő között. ${ }^{23} \mathrm{~A}$ második, új Földtörvény "expressis verbis" nem szól sem a haszonbérleti szerződésről, sem a részesmüvelésről. ${ }^{24}$ Ennél fogva a haszonbér, valamint a részes-múvelő díjazásának természetbeni lehetőségéről sem. A magyar tételes-jog e kérdésről diplomatikusan "semmit mondani látszik" (nullum dicere videtur).

Ennek oka, hogy a magyar kormány agrárpolitikája jól látja, hogy bizonyos termőterületi méreteket meghaladó agrárgazdaságok előszeretettel alkalmazzák a termőterületeik részesművelésbe adását, mégpedig legtöbbször vállalkozási szerződéskötés formájában. Ebben az esetben minden további nélkül vállalkozási díjként jogszerűen kiköthető a betakarított terménynek a megosztása a részesmúvelésbe adó cég és a részes-művelő között. Ez vonatkozik olyan területnek a müvelésbe adására is, ahol a munkálatok nem kerülnek a cég és a megmüvelő közötti megosztásra, vagyis, ha a müveléssel kapcsolatos jogviszony a haszonbérleti szerződéshez hasonlít, abban az esetben, ha a szerződést vállalkozásink címezve kötik meg. Abban az esetben azonban, ha az ilyen természetbeni dijazású földtulajdonosi részvételével, valamint ilyen részvétel nélkül csak a termelő által egyedül történő művelési jogviszonyt részesművelésnek, vagy haszonbérleti szerződésnek címezik az azt megkötő felek, a magyar jog szempontjából is jogellenes, mivel Magyarország csatlakozott a haszonbérleti jellegü földhasználat természetbeni díjazását tiltó ILO egyezményhez. Hogy ezt mégis lehetséges jogkövetkezmények nélkül megtenni, adódik abból, hogy az ILO nem fordít gondot az ilyen jogsértések felderítésére és jogkövetkezmények alá vonására, a magyar joggyakorlat pedig szintén nem alkalmazza a palástoló szerződések érvénytelenségét kimondó Ptk. 6:92. §-át. Ezzel összefüggésben azonban indokolt megjegyezni azt, hogy az érvénytelenség nem alkalmazható abban az esetben, ha a haszonbérleti, vagy a részesmúvelési díj a termés egy részében, valamint pénzben vegyesen kerül megállapításra és a pénzbeli arány több mint a természetbeni. ${ }^{25}$ Mind ez még egyértelmúbb abban az esetben, ha az itt tárgyalt részesművelési szerződési módozatokat munkaviszonyként kötik meg.

\footnotetext{
22 Prugberger: Tagsági megállapodások a szövetkezetekben. 1979. 212-223. 0.; U.ő: A szövetkezet és a tagok vagyoni, valamint vállalkozási kapcsolatainak jogi kérdései. SZKI, Közlemények, 185. 85-86. 0.

23 1994: V. tv. III. fejezet

24 2013: XXII. tv. IV. fejezet 10-14. pontjai a feles-bérletről és a részesmüvelésről semmilyen formában sem tesz említést

${ }^{25} \mathrm{Az}$ ILO egyezmény értelmében a munkabérnek a természetbeni része nem haladhatja meg a pénzbeli rész $50 \%$-át
} 
Az agrárgazdaságok zöme azonban inkább a vállalkozási szerződéskötést preferálja, mivel ez esetben a kötelező társadalombiztosítási járulékot teljes egészében a részes-müvelő, valamint a „kvázi haszonbérlő" mint vállalkozó viseli. Munkaviszonyként az ilyen szerződést legfeljebb akkor köt, ha munkaerőhiány áll fenn a piacon és a részesmüvelést felvállalók ragaszkodnak ahhoz, hogy a foglalkoztató gazdaság munkaszerződésként kösse meg velük a szerződést és a kötelező nyugdíj-, és egészségbiztosítás járulékainak nagyobb hányadát munkáltatóként ő fizesse. ${ }^{26}$

\section{Atipikus foglalkoztatási formák az állattenyésztésben és a mezőgazdasági segédüzemekben}

\subsection{Foglalkoztatási módozatok a nagyüzemi állattartás esetében.}

Nagyüzemi állattartás esetén, ide értve nemcsak a tartást, hanem a nevelést is, különösen szárnyasok és kisállatok keltetése és felnevelése tömegistállókban történik, ahol az etetés, a fejés és a gondozás elvégzésének az idején kívül is többnyire állandó felügyeletre van szükség. Ezért az alvási időn kívül napközben a legtöbb gazdaságban két műszakban az állatgondozói munkakörben dolgozók kora reggeltől, amikor az első etetés történik, egészen késő estéig az állatok lepihenéséig az állatgondozási és tenyésztési telepen vannak. Az agrárgazdaságok egy igen jelentős részében azonban éjszakai felügyelet van. Ezért az ott dolgozók nem két, hanem három müszakban váltják egymást. Ha a két-, és három müszakos munkavégzés munkajogviszonyban történik, egyértelműen a többmüszakos munkavégzésre vonatkozó munka-törvénykönyvi elő́rások alkalmazandók. Így az ott meghatározott éjszakai müszakra járó $15 \%$-os pótlék, ${ }^{27}$ a kétmüszakos munkavégzés esetében pedig a délután 6 órától a másnap reggel 6 óráig tartó időszakra 30 \% müszakpótlék jár annak aki, ez alatt az időszak alatt legalább egy órát dolgozott ${ }^{28}$. Munkaviszony esetén az állatgondozói munkakörben dolgozók többnyire határozatlan időre szóló munkaszerződéssel teljes munkaidő kitöltésére vannak foglalkoztatva.

Több nagyüzemi agrárgazdaság azonban korábban tartalmilag belső vállalkozási jogviszony keretében foglalkoztatta formális munkaviszonyt létesítve a cég egyes állattenyésztési telepein dolgozó munka kollektívákkal. Az egyes személyekkel megkötött munkaszerződés formalizmusa mögött az adott telepen dolgozó munkakollektívával a cégvezetés csoportos átalány-elszámolási szerződést kötött, amelynek alapján a cég meghatározta azt a nyereségtömeget, amelyet az egységnek ki kellett kitermelnie. Ebből a kigazdálkodott jövedelemből kellett az egységnek kifizetnie az üzemeltetéssel kapcsolatos rezsi költségeket, az egyes tagoknak járó munkadíjat valamint a társasági-, illetve a jövedelemadónak az adott egységre vonatkozó részét. Ilyen belső átalány-elszámolási szerződést az egyes agrárgazdaságok nemcsak az egyes belső csoportvállalkozásokkal, hanem egyéni

\footnotetext{
${ }^{26}$ L. a 8. sz. jegyzetet

27 Mt. 142. §

${ }^{28} \mathrm{Mt} .141 . \S$
} 
átalány-elszámolásban dolgozókkal is kötöttek. ${ }^{29}$ A mezőgazdasági termelőszövetkezeteknél a munkaviszony létesítésnek ez a formája az 1970-es évek közepétől általános gyakorlattá vált, ${ }^{30}$ amit az 1980-as évek közepétől az álam vállalatok is átvettek. ${ }^{31}$

A csoport és egyéni vállalkozási foglalkoztatásnak ez az átalány-elszámolásos formája a nagy agrárgazdaságokban a csoportos és az egyéni állatgondozás esetében ma is sikerrel alkalmazható mind munkaviszony mind tartós vállalkozás formájában. Az utóbbi a gazdaság számára kifizetődőbb a már tárgyalt társadalombiztosítási járulékrendszer miatt, mivel a járulékfizetési kötelezettség ez esetben kizárólag a vállalkozót terheli. A mezőgazdaságban fennálló csekély munkaerö-kínálat folytán azonban könnyen előfordulhat, hogy állatgondozóhoz a gazdaság akkor jut, ha viseli a nyugdíj-, és egészségbiztosítása járulékának a törvényben meghatározott hányadát.

Az állatgondozói telepen, fedett helyen, vagyis istállóban történő állattartás és állatgondozás, illetve nevelés esetében az állatgondozói munkakör - függetlenül attól, hogy azt vállalkozási, vagy munkaviszony formájában látják el - magába foglalja az állatgondozáson kívül az istálló és az állat körletének a rendben tartását, a megfelelő hőmérséklet biztosítását, a napszaki időpontokhoz kötött etetésről és itatásról való gondoskodást és a takarmánybehordást is. Rideg állattartás, valamint nyári legeltetés esetében a munkakör a megfelelő legelőre történő kihajtás és a hazahajtás, valamint a legelőn való tartózkodás idején az őrzés és a terelés, továbbá a rendszeres itatásról való gondoskodás a pásztor feladata. Abban az esetben, ha naponta a telepről a legelöre történő kihajtásra és onnan napnyugtakor a visszahajtásra kerül sor, a napi munkaidőt általában 12 órában állapítják meg a 12 havi munkaidőkeret figyelembe vételével, vagy pedig ketten látják el e feladatot váltott müszakban. A kihajtásra és a behajtásra vonatkozó időt ugyanis mind a magyar Mt. elöírásai, mind pedig az Európai Törvényszék legújabb gyakorlata szerint nem ügyeletnek vagy készenlétnek, hanem rendes munkaidőnek kell tekinteni. ${ }^{32}$ Abban az esetben, ha éjszaka is kint vannak az állatok, legtöbbször a három műszakos megoldás alkalmazására kerül sor napi 8 órás munkaidő figyelembe vételével abban az esetben, ha az állatfelügyeletet (pásztor) munkaviszony formájában látják el. Ebben az esetben is az agrárgazdaságok, hogy a munkaviszonnyal járó munkaidő-kötöttségektől szabaduljanak, inkább az őrzést tartós vállalkozási formában alakítják ki. Problémát ugyanis többek között az is okoz -miként erre Mélypataki a már többször hivatkozott tanulmányában is utal,

29 Prugberger: Tagsági megállapodások a szövetkezetekben, 70-78. 0.; U.ő: A szövetkezetek üzemszervezési egységeinek önállósodását megvalósító jogi eszközök SZKI. Közlemények, 169. sorsz. SZÖVORG, Bp. 1982. 34-61. o.

30 Prugberger: A belső vagyoni és vállalkozási jogviszonyok az önkormányzati vállalatoknál. SZKI. Közlemények, 206. kötet, SZÖVORG. Bp. 1988. 90-106. o.

${ }^{31}$ Előző jegyzetben hiv. mü, 101-103. o.

32 Mt. 86. §; Lásd továbbá: Sipka Péter-Zaccaria Márton Leó: Dolgozik és pihen? A munkaidő fogalmának bővítése az Európai Unió bíróságának újabb ítélete nyomán, tekintettel a magyar bírói gyakorlatra. Jogtudományi Közlöny, 2016/9. sz. 448-457. o.; Prugberger: A munkaidő, pihenőidő és a szabadság új hazai szabályozásának a megítélése a munkavállalói érdekek szempontjából. Pro Futuro, 2017/2. sz. 32-39. o. 
hogy a 2012. évi új Munka Törvénykönyv leszükítette az 1992. évi korábbi Mt.-ben az idényjellegű munkavégzésre a munkaidő keretnek a korábbi 12 havi, illetve 52 hétre történő kiterjeszthetőségét a mezőgazdaságban is csak 6 hónapra, illetve 26 hétre. Ezen kívül erre is csak kollektív szerződéssel van mód, a legtöbb gazdaságban viszont nincs a mezőgazdasági ágazat szakszervezeti szövetségének olyan képviselete, amelyik a leszűkített munkaidőkeret-meghosszabbításra vonatkozó kollektív szerződést megkötné. ${ }^{33}$

\subsection{A munkavégzés formái a segédüzemi és a termékfeldolgozói} tevékenységekben. A segédi és a termékfeldolgozói tevékenység önálló üzemágként csak a nagy farmgazdaságoknál jön számításba, mivel a kis-, és közepes egyéni és családi gazdaságoknál nagyobb géppark nincsen és a termékfeldolgozás is elsősorban elsődleges feldolgozás és elsődlegesen helyi piaci értékesítésre történik az eloaállítás, nem pedig nagyobb körzeteket érintő élelmiszerkereskedelemre szánt tartósított nagy tételű gyári tömeges elóállításra. Ennél fogva a közepes és annál kisebb méretű gazdaságokban mind a gépek karbantartása, javítása és használata rugalmasan valósul meg, általában a család munkaerejével, esetleg alkalmi, vagy részmunkaidős alkalmazott vagy vállalkozó igénybevételével. Ezzel szemben a nagy agrárgazdaságok legtöbbször kombinált agrártermesztő és élelmiszeripari feldolgozó cégek, ahol mind a mezőgazdasági termelés gépi kiszolgálását, valamint a géppark karbantartását és müködőképes állapotban tartását általában fix munkaidős egy müszakban látják el. A mezőgazdasági tevékenységnek ez a gépi kiszolgálása magába foglalja a növénytermesztés és az állattenyésztés, valamint a termékfuvarozás valamennyi ágát. Van, ahol a gépkocsivezetők, akik a termékfuvarozást és a termeléshez szükséges anyagbeszerzést végzik, a karbantartó üzemághoz tartoznak, a legtöbb esetben azonban külön üzemágat képeznek, mivel a gépi karbantartók tevékenysége a mühelyhez kötött, a gépkocsivezetőké pedig változó helyekre, változó munkaidőben valósul meg. Ennél fogva, ahol a gépkocsivezető állandóan az ő használatába adott kocsival jár, a tisztántartásáról és az üzemképes állapotáról neki kell gondoskodnia, így a kisebb szerelési munkákról is. Abban az esetben is azonban, ha a gépkocsivezető a kisegítő üzemághoz van besorolva, munkaideje hosszú, általában 6, vagy 12 hónapos munkaidőkeretben van meghatározva, kötelezően igénybe venni köteles munkaközi szünetét és pihenőidejét pedig közlekedési jogszabály írja elő. A karbantartó műhelyekben dolgozók általában egy műszakban dolgoznak, délután pedig legtöbb agrárgazdasági végnél csak ügyelet van, amit sorrend szerinti beosztással egymást hetenként felváltva látnak el a karbantartók és a szerelők. Igen sok helyen nem ügyeleti díjat, hanem rendes munkabért számolnak el a részükre a hosszabb munkaidőkeret figyelembe vételével. ${ }^{34}$

A helyi piacra szánt nagyobb tételü elsődleges mezőgazdasági termékfeldolgozó üzemágban (savanyúságok, káposztaféleségek, lekvár, kompót, tej, tejföl, sajt, túró, kolbász, stb.) az ott dolgozók többnyire egy műszakban látják el

\footnotetext{
33 Mélypataki, 7. sz. alatt hiv. mü 79-80. o. (2.1. pont)

${ }^{34}$ Közvetett információ észak-, és nyugat-dunántúli cégektől
} 
munkakörüket, míg a nagy tételü és legtöbbször tartósított, valamint gépi csomagolású ipari méretü, kereskedelmi célú élelmiszerszer-előállítás fix munkaidőben egy vagy két müszakban bonyolódik le.

\section{A saját egyéni-családi gazdaságban termékfeldolgozó cég részére végzett termesztés és állatnevelés}

Az 1990. évi rendszerváltást megelőzően a mezőgazdasági termelőszövetkezetek részben az 1959. évi régi Ptk. XXXVI. fejezetébe foglalt termékértékesítési és állatnevelési szerződéseket kötöttek részben saját tagjaik háztáji gazdaságával, részben pedig kívülálló gazdákkal is. Jogdogmatikailag e szerződések, ha előre nem állapodott meg a termesztő, és az állatnevelő gazda a szövetkezettel, vagy az állami gazdasággal, adás-vételi jellegüek voltak, ha viszont előre megállapodtak és a növendék állatokat felnevelésre a szövetkezet vagy az állami gazdaság adta a tagi, vagy a dolgozói háztáji gazdaságnak, akkor az vállalkozási jellegü volt. Tekintettel arra, hogy a mezőgazdasági szövetkezeti törvény (Mgtsz Tv.) kimondta, hogy a közös és a háztáji gazdaság szerves egység, amit gyakorlatilag a munkaviszonyban álló dolgozóikkal fennálló hasonló jellegú kapcsolataik tekintetében az állami gazdaságok is alkalmaztak, ezt munka-, illetve tagsági munkaviszony keretében történő házi bedolgozásként tartották nyilván és az ellenértéket bérként számolták el. Analógiaképpen a az állami vállalati és az ipari szövetkezeti házi bedolgozást alkalmazták, többnyire azzal, hogy a nevelésre átadott újszülött állatok értékét a mennyiség alapján megállapították és az átadáskor megállapított értéket a felnevelt állatok átadásakor a felnevelt állatok értékéből levonták. Így a természetes elhullás, valamint az olyan elhullás veszélye, amelyért nem felelt a nevelést végző gazda, a veszélyt a termeltető, neveltető mezőgazdasági szövetkezet, illetve állami gazdaság viselte. Ezek lényegében a gazdaság és a tagja, illetve munkavállalója között létesült adás-vételi jellegü belső termékértékesítési, legtöbbször azonban --különösen az állat felnevelés terén-vállalkozási jellegü szerződések voltak. A gazdaság vette meg a költőállomástól, vagy maga költötte ki a naposcsibéket, napos kacsákat és a napos libákat, egyszóval az étkezési napos szárnyas állatokat, amelyeket a takarmánnyal együtt átadták a gazdáknak. A takarmányról is az állat neveltető gazdaság gondoskodott. Ugyanez volt a helyzet akkor is, ha a gazdaság meghatározott típusú növényeket, többnyire gyógynövényeket, vagy nemesített vetőmagot termeltetett. Ez jogdogmatikailag olyan vállalkozási szerződésnek minősült, ahol a megrendelő szövetkezet, vagy állami gazdaság, gyakran azonban közvetlenül a gyár, legtöbbször valamely gyógyszergyár adta termesztésre a speciális vetőmagot, amelynek árát a termés átadásakor a megrendelő levont. Ez a növénytermeltetési jogviszony lényegében hozott anyagból történő vállalkozási szerződésnek minősült. Attól függően volt vállalkozás, illetve munkaviszonynak minősülő belső vállalkozás, hogy a megrendelővel a termelő, illetve az állatfelnevelést végző gazda mg. tsz 
tag, vagy állami gazdasági dolgozó, vagyis belső személy, vagy kívülálló volt. ${ }^{35}$

A rendszerváltást követőn a Magyarországra betelepedett multinacionális élelmiszer-áruházak és élelmiszer előállítást végző cégek a kistermelő gazdaságokkal az ilyen termeltetési és állatfelnevelési szerződéseket oly módon megváltoztatva kötik meg, hogy az szín tiszta polgári jogi jellegű vállalkozási szerződés és az átadott vetőmagot, valamint a nevelésre átadott napos állatok árát azonnal kifizettetik, és ugyanígy kifizettetik előre a nevelési időszak alatt folyamatosan leszállításra kerülő takarmány árát. Egyúttal kikötik azt is, hogy a termék, illetve a felnevelt állatok másutt nem értékesíthetők. $A z$ is előfordul, hogy az állatnevelési, valamint a termeltetési szerződéskötés során a megrendelő cég kikötése alapján a nevelést, vagy a terelést végző gazdaságnak kell a napos állatokat, a takarmányt, a gyógyszert, a vetőmagot és a növény-védőszert a saját költségére és veszélyére beszerezni, a megrendelő gazdaság pedig semmilyen közremüködést nem vállal. Ilyen ok miatt ment tönkre és vált földönfutóvá a Hajdú BÉT-tel libanevelési szerződést kötött mintegy száz egyéni-családi gazdaság, mivel a Hajdú BÉT-et a hozzá nem értő vezetés csődbe vitte, és ennek ellenére hitegette, hogy átveszi a felnevelt libákat, amire azonban nem került sor és az állatok a nevelést végző gazdaságokban tömegével a kiéheztetéstől tömegesen elhullottak. A Hajdú BÉT súlyos szerződésszegése ellenére a kártérités és a csődbűntett alól az akkori balliberális politika segítségével ki tudott bújni. ${ }^{36}$ Hogy ilyen esetekre a jövőben ne kerüljön sor, a fogyasztóvédelmi szervezeteknek, és az agrárszakigazgatási szervezeteknek valamennyi állatnevelési és termeltetési szerződésblankettát át kellene vizsgálniuk. Abban az esetben, ha azokban a blanketta kibocsátó cégek minden beszerzést és veszélyviselést a vállalkozó állatnevelöre és a termelőre hárítanak, elő kellene írni, hogy a Ptk. 6: 105. §-a alapján közérdekü keresettel támadják meg a bíróság előtt az ilyen joggal visszaélést tartalmazó tisztességtelen szerszerződési feltételeket tartalmazó blankettákat. Ez okból indokolt lenne elöírni, hogy az ilyen növényi és állati termékek értékesítésével foglalkozó cégek kötelesek legyenek kibocsátásuk előtt valamennyi állatneveltetési és termeltetési szerződési feltételeiket tartalmazó blankettáikat a területileg illetékes agrárkamarának bemutatni. Az 1993. évi V. tv.-el életbe léptetett új Ptk.-ban a 6: 232. §-a (saját termelésű mezőgazdasági árú szolgáltatására kötött adásvételi szerződés) és a 6:333. §-a (a vevő közreműködésével előállított mezőgazdasági árú szolgáltatására kötött adásvételi szerződés) alapján lehet megkötni e szerződéseket. Az előbbi a korábbi termékértékesítési szerződésnek, az utóbbi a korábbi tereltetési és állatnevelési szerződésnek felel meg.

\footnotetext{
${ }^{35}$ L. a 12., a 20. és a 21 . jegyzetet

${ }^{36}$ A Hajdu BÉT csődbe kerülésével és a Hajdu BÉT-el libanevelési szerződést kötő gazdák emiatti egzisztenciális tönkretételével kapcsolatos 2002/2003. évi és a megindult elhúzódott jogi eljárással összefüggő tényfeltáró 2012/13. évi cikkeket lásd a Magyar Nemzet, a Magyar Hírlap, a Demokrata és a Kapu c. folyóiratok eme időszakban megjelent számaiban.
} 


\section{Külföldi mezőgazdasági munkavégzési formák}

Japán az egyéni-családi agrárgazdálkodás mellett ismeri a több, nem nagy taglétszámú gazda kooperációjával létrejövő termelőszövetkezeti jellegü közös gazdálkodást. Hasonló jellegü közös mezőgazdasági termelői tevékenységre történő szövetkezés ismeretes Franciaországban is. Többnyire rokonok és szomszédos földeken dolgozó gazdák állnak össze és közösen müvelik földjeiket és folytatnak közös állattenyésztő tevékenységet. Ennek legalizált jogi formája a Grupement $d^{\prime}$ Agrar Cooperativ. ${ }^{37}$ Lehetőség van ennél nagyobb olyan termelőszövetkezetek alakítására is, ahol a tagok személyes szövetkezeti tagsági közremüködése a tagoknak a belső munkaszervezeti szabályzat és az arra illetékes szakvezető által meghatározott közös agrárgazdasági tevékenységben történő részvételében valósul meg. Ellentétben a más gazdasági ágazatokba tartozó szövetkezetekkel, amelyek nemcsak a Szövetkezeti Törvény (Loi d' Cooperativ) alapján szövetkezetként, hanem változó alaptőkéjű részvénytársaságként is múködhetnek, a mezőgazdasági ágazat szövetkezetei csak szövetkezeti formában müködhetnek a "loi cooperativ d' agrar alapján. ${ }^{38}$ Franciaországban ismeretesek olyan agrárszövetkezetek, amelyek önállóan gazdálkodó tagjaik számára beszerzőértékesítő szövetkezetként működnek, de vannak olyan tagjai is, akik a szövetkezet termelői, munkaszövetkezeti profiljában személyes közremúködésként munkatevékenységgel vesznek részt. Ezt a francia modellt ötvözte a volt jugoszláv agrárpolitika a szerb-horvát "zadruga" szövetkezeti formával, ahol a Zadruga egyfelöl szintén az egyéni gazdasággal rendelkező tagok számára beszerzőértékesítő szövetkezetként, míg az ilyennel nem rendelkező tagok munkavégzéssel működtek közre a Zadruga termelőszövetkezeti részlegében. ${ }^{39}$ Ausztriában egyes agrártermékeket, föleg zöldséget, gyümölcsöt, tejet, tejterméket és mézet árusító szövetkezeti üzletek eladói szövetkezeti tagsággal rendelkező eladói tevékenységet végző tagok, kiknek a személyes közremúködése a szövetkezet működésében lényegében munkavégzés, míg azoknak az egyéni tag-gazdák részére, akiknek a termékeit a szövetkezet árudája értékesíti, értékesítési formában kötődnek a szövetkezethez. ${ }^{40}$

Tipikusan termelőszövetkezeti formában müködtek még a XX. század végén is, azonban fokozatosan elhaltak azok a mexikói szövetkezetek, amelyek a mexikói forradalom során alakultak meg a nagybirtokok nacionalizálása után azok helyén kialakított ejidok. Az állam a nacionalizált nagybirtokokat szétosztotta az agrártevékenységből élő földnélküli, vagy csak kisgazdasággal rendelkező

\footnotetext{
37 Perczell János (szerk.): Vállalkozók, vállalkozások a termelőszövetkezetekben. Mezőgazdaági Kiadó, Budapest, 1989.

${ }^{38}$ Jan Hammel: Droit commercial, Dalos, Paris, 1954.; Süveges Márta: A szövetkezet jogi formája és természete a piacgazdaságban.In: Szövetkezés, 1991/1. sz. 6-7. o.

${ }^{39}$ Savo Cukanovic: Zemiljoradnocko zadrugarstvo u agrajnoj politici Jugoslavie. NIP. Mala poljopriuredna biblioteke. Beograd, 1971.

40 Informácio Diplom ökonom Karl Zehetnertől, az Osztrák Munka-, és Szociálisügyi Minisztérium keretében működő Vállalkozóképző Intézet igazgatójától. Bécs, 1980május a Szövetkezeti Kutató Intézet által finanszírozott ausztriai tanulmányút, a Reufeisen Akadémiához (RAK). Bécs, Insbruck, Salzburg.
} 
agrárnépesség között, akiket ejidokba szervezett. A kezdeti ejidok egyik formája kommunaként müködött, de ez a forma hamar kifulladt és munkaszövetkezeti jellegű ejidokká alakultak át, amit a tagok kollektív munkavégzése jellemzett. A munkaszövetkezeti jellegü ejidók mára fokozatosan beszerző-értékesítési szövetkezet jellegű ehidókká alakultak át. ${ }^{41}$ Némileg hasonlít ehhez a rendszerhez az izraeli kibuc és moshav rendszer. A kibuc kommuna típusú együttélést és közös munkatevékenységet jelent, míg a moshav a termelőtípusú munkaszövetkezetekhez hasonlít. Mind a kibucokban, mind a moshavokban a munkavégzés sokszínű, azonban uralkodó jellege a mezőgazdasági tevékenységnek van. ${ }^{42}$

Végezetül a szegényebb latin nyelvű régiók mezőgazdasági munkaszövetkezeti formáról szólva először a spanyol portugál mondragon szövetkezeti mozgalmat kell megemlíteni, amely mezőgazdasági munka-szövetkezetént tagi munkavégzéssel funkcionál. Ezen kívül Olaszországban vannak földbérlő termelőszövetkezetek, amelyeknek egyik ágra az jellemző, hogy egy vagy több gazdasági évadra földbirtokosoktól bérbe veszik a mezőgazdasági üzemet és azt a korábbi magyar rendszerhez hasonlóan a föld-, illetve az agrárgazdaság tulajdonosának bért fizetnek és az ezen felüli jövedelemmel a szövetkezet rendelkezik. E földbérlő szövetkezetek a tagjaik irányában munkaszövetkezetként működnek. A földbérlő szövetkezeteknek másik ága tulajdonképpen nem bérlő szövetkezet, hanem olyan csoportos munkaszövetkezet, amely meghatározott térítés, vállalkozói díj ellenében vállalja, hogy minden gazdasági tevékenységet elvégez a gazdaság tulajdonosának. Ez a szövetkezeti csoportos munkafelvállalás bizonyos fokig hasonlít a Magyarországon is elterjedt társas munkavállaláshoz azzal a különbséggel, hogy Olaszországban jogilag leszabályozott, míg nálunk inkább jogszociológiai jelenség. ${ }^{43}$

\footnotetext{
${ }^{41}$ Walter Preus: A szövetkezeti mozgalom a világon és Izraelben. SZKI. Közlemények, 35. kötet

$42 \mathrm{U}$. ott

43 Pedrini Palmierini: Das Produktionsgenossenschaftswesen in Italien, dargestellt in Beispiel bestimmter Landarbeitergenossanschaften. In: Zeitschrift für das gesammte Genossenschaftswesen. Band 26. (1976). Heft 1.
} 